«Системні технологіï» 6 (125) 2019 «System technologies»

DOI 10.34185/1562-9945-6-125-2019-06

UDC 681.5.015

A.I. Guda, A.Yu. Zimoglyad

\title{
SIMULTANEOUS IDENTIFICATION OF THE ALL PARAMETERS FOR THE LORENZ CHAOTIC SYSTEM
}

Abstract. Drawbacks of the adaptive-searching methods, related with the problem of multiparameter dynamic system identification are explored and highlighted. New approach, based on "moving regression" method is proposed. New approach is a hybrid method; it combines features of the "moving average" method, linear regression method and differential system representation. This combination allows to simultaneously determining complex dynamic system parameters, in spite of its chaotic behavior and measurement errors. New method possibilities are explored via identification process numerical simulation for the Lorenz chaotic system. Keywords: chaotic systems, parametric identification, non-linear dynamic system identification.

Introductio. Correct, reliable and effective functioning is a critical requirement for the modern control systems. Achievement of such goal is impossible without existence of the adequate models, simulation methods and equipment. Models under consideration (and, obliviously, related systems) is often demonstrates complex, even chaotic behavior [2,5]. Moreover, essential number of the parameters converts the identification task to a real challenge.

Non-empty set of the identification methods, suitable for complex and chaotic systems identification, exist and used with some order of success. Adaptive-searching methods, especially methods with ensemble of the searching agents appear to be most effective and proven $[1,4,6]$. Nevertheless, direct utilization of such methods is not so straightforward. First of all, a synthesis of the suitable criterion is not a simple and obvious task. For many chaotic systems such criteria was created [5], both using physical and empirical approaches. But, in general, the is no algorithm to criteria generation.

(C) Guda A.I., Zimoglyad A.Yu., 2019 
«Системні технологіï» 6 (125) 2019 «System technologies»

One more essential drawback of these methods exists. Existence of the single scalar criteria does not allow us to conduct identification, if the number of the parameters is more the one. Moreover, if the number of the criteria is equal to the number of the parameters, the final identification algorithm is still undetermined in most cases.

Thereby, creation of the methods and algorithms, suitable for the identification task solving in the case of the several parameters is an actual problem.

Task definition. As the probe task, let's consider classical Lorenz dynamic system [2]:

$$
\left\{\begin{array}{l}
\dot{x}(t)=\sigma(y(t)-x(t)), \\
\dot{y}(t)=x(t)(r-z(t))-y(t), \\
\dot{z}(t)=x(t) y(t)-b z(t) .
\end{array}\right.
$$

where: $x(t), y(t), z(t) \quad$ system state and outputs, $r, b, \sigma \quad$ parameters. System outputs measured with some errors: $w_{x}(t), w_{y}(t), w_{z}(t)$.

An adaptive-search method with ensemble of the agents allows as to reach identification goal for every single parameter [3,6]. For example, in the figure 1 identification process for the parameter " $r$ " is represented in the case of non-steady parameter value and in the presence of measurement noise.

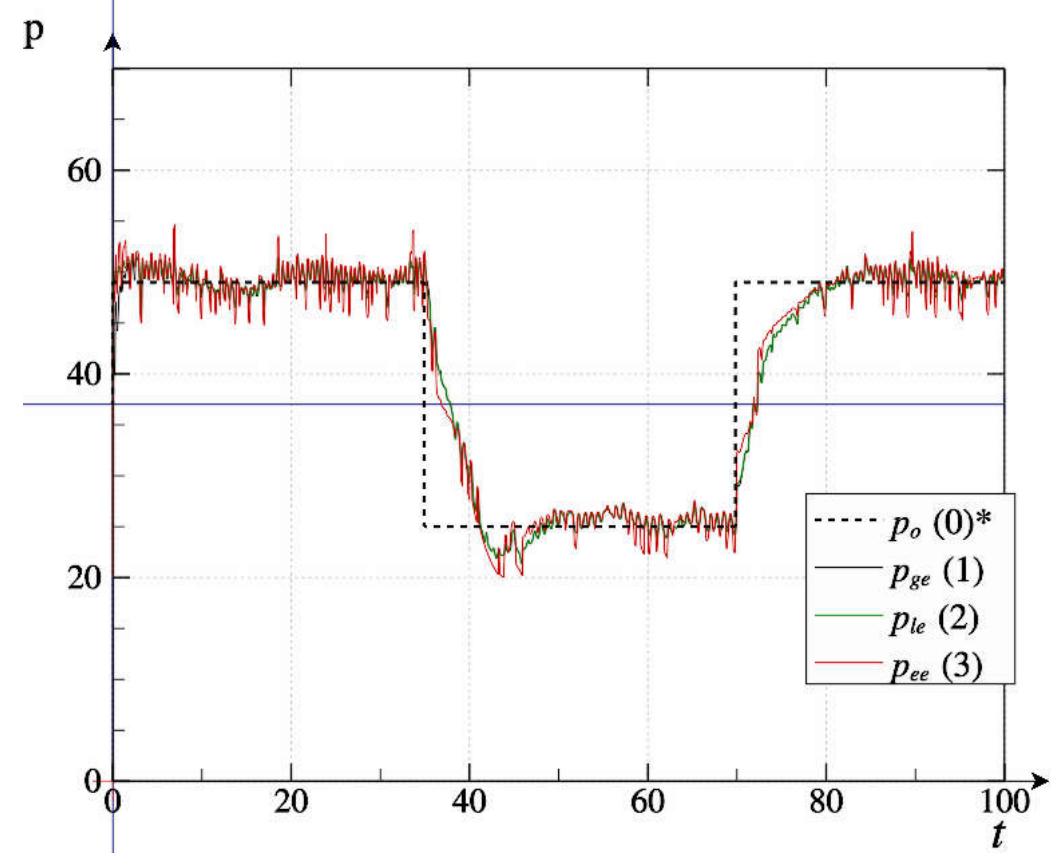

Figure 1 Identification process for the Lorenz system " $r$ " parameter using the adaptive-search methods with ensemble of the agents 
«Системні технологіï» 6 (125) 2019 «System technologies»

In spite of successive identification of every parameter, there is no direct expand to the case of non-single parameter. As for justification, we consider dependencies of the some used criteria for only one pair of parameters (figure 2).
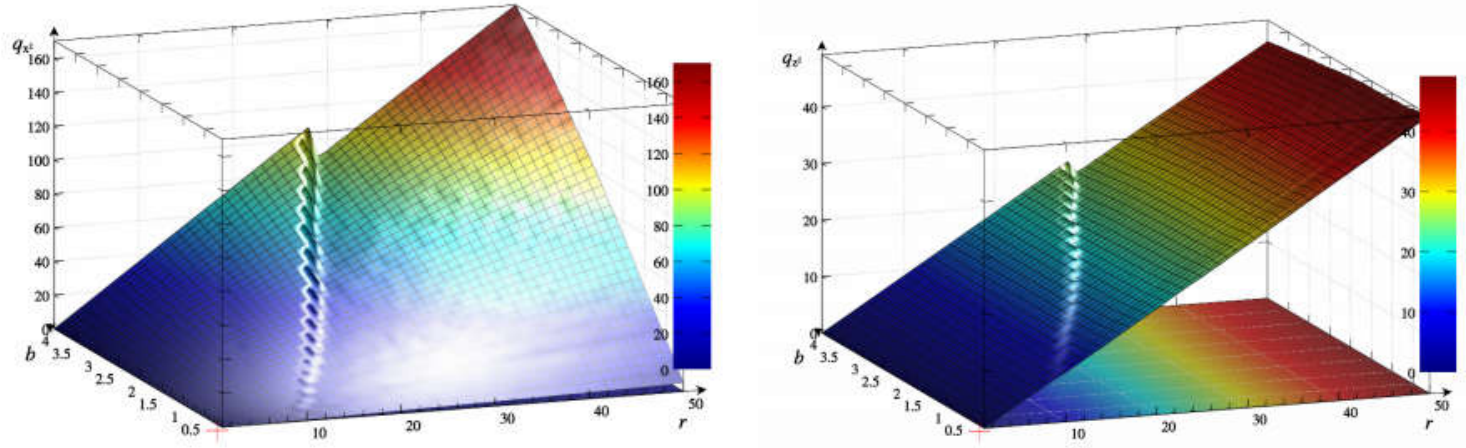

Figure 2 Criteria dependencies for the system (1)

The analysis of these dependencies shows us, that, if all parameters, except one, is steady, the identification becomes not a complex task, and the existence of the single criterion is sufficient. The task is equivalent to finding intersection of the criterion curve with measured criterion value. Good criterion will provide us the only intersection point in the working area. On the other hand, if we have two or more parameters to identification, a set of criteria is required, but not sufficient for identification. In this case each criterion provides a curve in the surface, and parameter values must me in the intersection of these curves (two-dimetional case). Obviously, this task is much more complex, and vulnerable even to small measurement errors. The more dimensions we have, the more complex and sensitive to measurement errors task we encounter. If we neglect the non-steady nature of the all parameters, then wrong identification results we receive.

As an example, let's consider the same identification process, as was used in figure 1 , but at the time mark $t=50 \mathrm{~s}$ second parameter (" $b$ ") will be changed. A simulation result (figure 3) emphasizes this quite obvious fact: changes in the values of the second (and so on) parameters lead to wrong result without any indication of the error. 


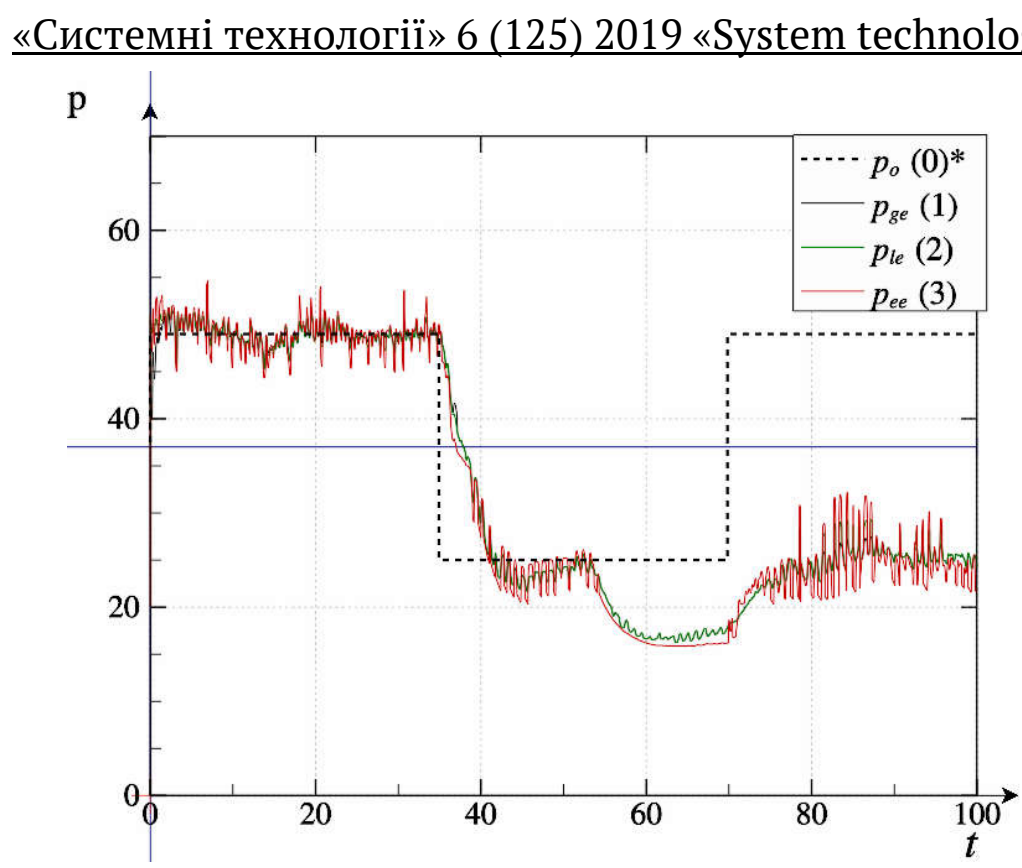

Figure 3 Identification process for the Lorenz system " $r$ " parameter using the adaptive-search methods with ensemble of the agents, in the case of non-steady " $b$ " parameter

So, multiple parameter identification task require new approach development.

Analysis of the problem. Criterion synthesis based both on physical or empirical approaches, is somewhat artificial process, if we have well defined model, which is defined in the terms of differentiation, integral or other mathematical form. In this representation, model parameters itself acts as a criteria, and describes the system behavior. Often these parameters is not separated, but there exists a large set of methods to make separation both analytically and numerically. Consequently, if we can derive required parameters from the system output, the identification task goal will be reached.

In the abstract case, without measurement errors, the task may be treated as quite simple. For the system under consideration (1), the parameter values can be expressed as:

$$
\begin{gathered}
\sigma=\frac{\dot{x}(t)}{x(t)-y(t)}, \\
r=\frac{\dot{y}(t)+x(t) z(t)+y(t)}{x(t)},
\end{gathered}
$$


«Системні технологіï» 6 (125) 2019 «System technologies»

$$
b=\frac{\dot{z}(t)-x(t) y(t)}{z(t)} .
$$

In practice, the equations (2) (4) are absolutely unusable. First of all, we have derivatives $\dot{x}(t), \dot{y}(t), \dot{z}(t)$. In the real word, we measure signals $x(t)$, $y(t), z(t)$ with some error. Moreover, realistic measurement, conducted, by example via ADC, demonstrates step alike behavior, which, in turn, leads to huge spikes in derivatives. We can suppress such phenomena by applying different filters, but in this case the type and parameters of the filter have more influence to value received, than signal itself.

In our examples there is one more essential hazard. A value of the signals (or difference) exists in expression denominators. If these values are approaches to zero, influence of the measurement errors increased up to infinity. So, we have to develop more robust method to determine parameters.

To provide a background for such method, let's rewrite second subequation of the (1) as:

$$
\dot{y}(t)+y(t)-x(t) z(t)=x(t) r+0
$$

This is a form of the linear dependence:

$$
f=A v+B
$$

where $A=r, f=\dot{y}(t)+y(t)-x(t) z(t), x(t)=v, B=0$.

If $r=$ const, we can use linear regression to determine $A$ and $B$. The value of $A$ gives us a parameter " $r$ " itself, and the value of “ $B$ ” provides some type of indication. If we have correct measurement and model, this value must be relatively small.

But if $r(t) \neq$ const this method requires some improvement. One of the famous statistical approach to make strong filtration is "moving average". We can make a "hybrid" method: use "moving average" with the window size $t_{m r}$ to accumulate sums for regression. Such method we define as "moving regression", and will be denote as $R_{m}(v, f)$. Thus, to determine the $r, b, \sigma$ values we will use:

$$
\begin{gathered}
\sigma=R_{m}(x(t)-y(t), \dot{x}(t)) \\
r=R_{m}(x(t), \dot{y}(t)+y(t)-x(t) z(t)) \\
b=R_{m}(z(t), \dot{z}-x(t) y(t))
\end{gathered}
$$


«Системні технологіï» 6 (125) 2019 «System technologies»

The $t_{m r}$ values can be determined by the same way, as $t_{a}$ values for identification criteria.

Simulation results. To verify the correctness and estimate the properties of the new approach, a simulation, similar to represented if fig. 1 was conducted in the "qontrol" simulation environment. The essential difference was added to simulation: all parameters was non-steady, and demonstrates step-alike dynamics. The simulation results, received with the aid of (6)-(8) are shown on the fig. 4.

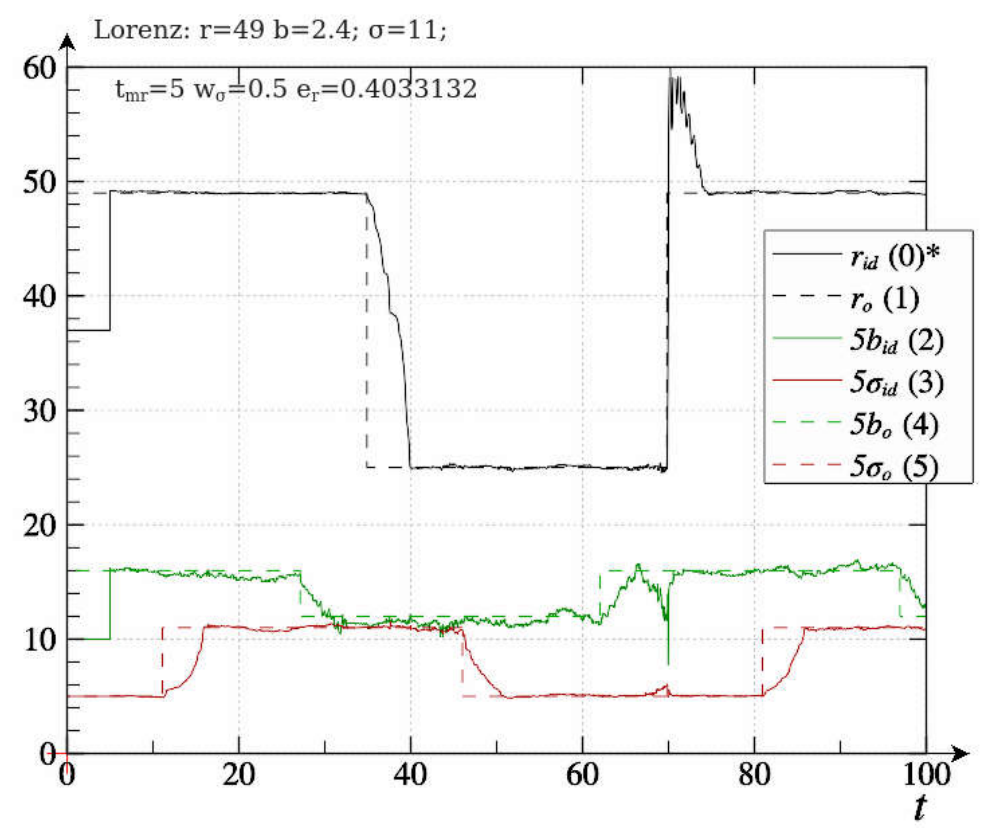

Figure 4 Identification process for the Lorenz system (1) by the use of new method

The results demonstrate that the new method is functional, and identification time and precision is near to the same for adaptive-search algorithms, but 3 parameters were identified simultaneously. Some influence of one parameter changing to the identified values of others is visible, but not have essential amount.

Conclusions. Using the results of the simulation, we can derive following conclusions:

1. Direct utilization of the criteria based approach in most cases can not lead to successful identification in the presence of more the one parameters. 
«Системні технологіï» 6 (125) 2019 «System technologies»

2. Formal deductions of the parameters values form the dynamic model is possible, but in the presence of the measurement errors gives us unusable results.

3. Approach, based on the moving regression, can provide us suitable identification results, if the window size is defined properly.

\section{REFERENCES}

1. Multi-model methods and parameters estimation approaches on non-linear dynamic system identification / Guda A.I., Mikhalyov A.I. // Регіональний міжвузівський збірник наукових праць «Системні технології», № 2'(103) 2016 - P. 57-62.

2. Sprott J.C. Strange attractors: creating patterns in chaos. - MT Books; 1993. -350 c.

3. Method of Lorenz systems parametric identification by the searching models ensemble objects / Guda A.I., Mikhalyov A.I. // Scientific and Technical Conference "Computer Sciences and Information Technologies" (CSIT) - 2015 - P. 73-75.

4. Adaptive-search system identification adjusting in application to chaotic objects / Guda A.I., Mikhalyov A.I. // Adaptive systems of automatic control. 2013. - № 22(42). - P. 134-139. (in russian).

5. Guda A.I., Mikhalyov A.I. Criteria synthesis problem for the chaotic systems identification // Proceedings of the 2016 IEEE 1st International Conference on Data Stream Mining and Processing, DSMP 2016, - Lviv, Ukraine, 08.2016. C. 125-128. - DOI: 10.1109/ DSMP.2016.7583522

6. Guda A.I., Mikhalyov A.I. Multi-models identification methods comparison in the non-linear dynamic system identification task // Радиоэлектроника, информатика, управление. - Запоріжжя, ЗНТу, 2016. - № 4. - С. 112119. - DOI: 10.15588/1607-3274-2016-4-14.

Received 09.12.2019. Accepted 11.12.2019.

\section{Одночасна ідентифікація всіх параметрів хаотичної системи Лоренца}

Досліджено та висвітлено недоліки адаптивно-пошукових методів, пов'язаних із проблемою багатопараметричної ідентифікації динамічної системи. Запропоновано новий підхід, заснований на методі «рухомої регресії». Новий підхід - це гібридний метод; Він поєднує в собі особливості методу "ковзаючої середньої", методу лінійної регресії та представлення диференціальної системи. Ця комбінація дозволяє одночасно визначати складні параметри динамічної системи, незважаючи на ї̈ хаотичну поведінку та помилки 


\section{«Системні технологіï» 6 (125) 2019 «System technologies»}

вимірювання. Досліджено нові можливості методу за допомогою чисельного моделювання процесу ідентифікації для хаотичної системи Лоренца.

Simultaneous identification of the all parameters for the Lorenz chaotic system

Drawbacks of the adaptive-searching methods, related with the problem of multiparameter dynamic system identification are explored and highlighted. New approach, based on "moving regression" method is proposed. New approach is a hybrid method; it combines features of the "moving average" method, linear regression method and differential system representation. This combination allows to simultaneously determining complex dynamic system parameters, in spite of its chaotic behavior and measurement errors. New method possibilities are explored via identification process numerical simulation for the Lorenz chaotic system.

Гуда Антон Игоревич - д.т.н, проф., доц. каф ИТС НМетАУ.

Зимогляд Андрей Юрьевич - асс. каф. ИТС НМетАУ.

Гуда Антон Ігорович - д.т.н, проф., доц. каф ІТС НМетАУ.

Зимогляд Андрій Юрійович - асс. каф. ІТС НМетАУ.

Guda Anton - doctor of technical sciences, professor, associate professor NMetAU. Zimoglyad Andrey - NMetAU. 